\title{
FIRST INTERNATIONAL CONGRESS ON HEMORHEOLOGY UNIVERSITY OF ICELAND, REYKJAVIK, 10-16 JULY, 1966
}

THE greater part of the current Number of Biorheology is devoted to Summaries and Appraisals of the work of this Conference. The Proceedings will be published in full in book form in a few months time. The Conference Chairman was Professor A. L. Copley. The Chairman of the Local Arrangements Committee was Professor Olafur Bjarnason, Chairman of the Department of Pathology at the University of Iceland and President of the Icelandic Medical Association.

The Conference, held under the auspices of the University of Iceland-Haskoli Islandsat its Festival Hall, was comprised of the Inaugural Session on July 10th, eleven working sessions on each day of the Conference from Monday, July 11th, to and including Saturday, July 16th, at which sixty-six original scientific contributions were presented, and the Closing Session. At the Inaugural Session, Welcome Addresses were given by Professor Armann Snaevarr, Rektor, on behalf of the host, the University of Iceland, and by His Excellency Dr. Gylfi Gislason, the Minister of Education, on behalf of the Government of Iceland. Other distinguished Icelanders, Professor Olafur Bjarnason and Dr. Asmundur Brekkan, also greeted the members and attendees of the Conference. This Session included the Inaugural Address entitled "On Hemorheology" by A. L. Copley, two lectures, one by Professor Hellmut Hartert entitled "The Significance of Hemorheology in the Practice of Medicine" and the other by Dr. George W. Scott Blair entitled "Hemorheology and the Physicist".

There was a delightful Social Program which included receptions given by the Minister of Education, His Excellency Professor Gylfi Gislason and his wife, by the Ambassador of the United States of America, His Excellency Mr. James K. Penfield and his wife, by the Mayor of the City of Reykjavik, The Honorable Mr. Geir Hallgrimsson and by the City Health Commissioner, Dr. Jon Sigurdsson and his wife. Tours of the National Museum and National Gallery of Art were made under the guidance of their Directors Mr. Kristjan Eldjarn and Dr. Selma Jonsdottir, respectively. A film and lecture on the birth of the island of Surtsey was given at the University by the geologist Dr. Sigurdur Thorarinsson, Director of the Museum of Natural History. The Social Program included visits to other museums, to hospitals, schools, etc. and a trip to Thingvellir, the site of the ancient Icelandic Parliament. The Ministry for Foreign Affairs of the Government of Iceland delegated its Press Officer, Mr. Bjarni Gudmundsson to address the Conference members and attendees at Thingvellir with a lecture on the history of the Icelandic Parliament. There was a special Social Program also for those ladies who were attendees of the Conference.

The occasion was also marked by two other events.

The first was the presentation of a Gold Medal, named in honour of Poiseuille, to Professor Robin Fåhraeus (Emeritus Professor of Pathology, University of Uppsala, Sweden) for his outstanding work as a pioneer in hemorheology. Secondly, a new Inter- 
national Society was founded to be called "The International Society of Hemorheology"* and the current Conference was included as its first activity. A Council and a number of Committees were set up. The names and addresses of the elected members of the Council are given immediately following this Introduction. It was resolved to draw up a formal Constitution before the Second International Congress to be held in France in 1969.

* See facing page for the list of Council including Officers. 


\section{THE INTERNATIONAL SOCIETY OF HEMORHEOLOGY}

\section{THE COUNCIL}

(A) Officers

President: Professor A. L. CoPLeY (U.S.A.), Hemorrhage and Thrombosis Research Laboratories, VA Hospital, East Orange, New Jersey; and Department of Pharmacology, New York Medical College, New York, New York.

Vice-Presidents:-Europe and Africa: Professor H. HARTERT (Germany), Medizinische Klinik, Städtisches Krankenhaus, Kaiserslautern and Medizinische Fakultät, Universität Heidelberg, Heidelberg; The Americas: Professor S. G. MASON (Canada), Department of Chemistry, McGill University, Montreal and Pulp and Paper Research Institute of Canada, Montreal; Asia and Australia: Professor S. OKA (Japan), Department of Physics, Tokyo Metropolitan University, Tokyo.

Secretary: Professor G. Bugliarello (U.S.A.), Biotechnology Committee and Civil Engineering Department, Carnegie Institute of Technology, Pittsburgh, Pennsylvania.

Treasurer: Professor S. WITTE (Germany), Medizinische Klinik und Poliklinik, der Universität Nürnberg-Erlangen, Erlangen, Germany.

\section{(B) Committee Chairmen}

(1) Blood Cellular Elements: Professor A. C. Burton, Department of Biophysics, University of Western Ontario, London, Ontario, Canada; (2) Clinical Hemorheology: Dr. J. Ditzel, Department of Medicine, Aalborg Municipal Hospital, Aalborg, Denmark; (3) Coagulation and Fibrinolysis: Professor K. M. Brinkhous, Department of Pathology, School of Medicine, University of North Carolina, Chapel Hill, N.C., U.S.A.; (4) Instrumentation: Professor Harold Wayland, Division of Engineering and Applied Science, California Institute of Technology, Pasadena, California, U.S.A.; (5) In vivo Hemorheology: Professor S. Rowlands, Physics Department, St. Mary's Hospital Medical School, University of London, London, England; (6) Link with Hemodynamics: Professor M. G. Taylor, Department of Physiology, University of Sydney, Sydney, N.S.W., Australia; (7) Model Studies and Extra vivum Hemorheology: Professor A. Silberberg, Polymer Department, The Weizmann Institute of Science, Rehovoth, Israel ; (8) Plasma Components and Modifiers: Dr. M. Joly, Service de Biophysique, Institut Pasteur, Paris, France; (9) Standards and Terminology: Dr. G. W. Scott Blair, Physics Department, National Institute for Research in Dairying, University of Reading, Shinfield, Berkshire, England; (10) Theoretical Hemorheology: Dr. R. L. Whitmore, Department of Mining Engineering, University of Nottingham, Nottingham, England; (11) Vessel Wall Hemorheology: Professor C. A. Wiederhielm, Department of Physiology and Biophysics, University of Washington, Seattle, Washington, U.S.A. 